\title{
Quality of Life and Characterization of Patients With Atopic Dermatitis in Portugal: The QUADEP Study
}

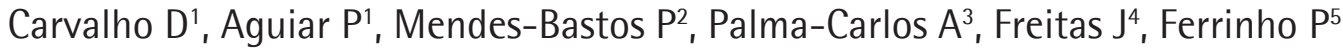 \\ 'NOVA National School of Public Health, Public Health Research Centre, Universidade NOVA de Lisboa, Lisboa, Portugal \\ ${ }^{2}$ Dermatology Centre, Hospital CUF Descobertas, Lisboa, Portugal \\ ${ }^{3}$ CAIC - Clinica de Alergia e Imunologia Clinicas, Lisboa, Portugal \\ ${ }^{4}$ Blueclinical, Senhora da Hora, Portugal \\ ${ }^{5} \mathrm{GHTM}$, Instituto de Higiene e Medicina Tropical, Universidade Nova de Lisboa, Lisboa, Portugal
}

J Investig Allergol Clin Immunol 2020; Vol. 30(6): 430-438

doi: 10.18176/jiaci.0443

\begin{abstract}
Objectives: To investigate the quality of life (QOL) of and to characterize patients with atopic dermatitis (AD) in Portugal.

Methods: This was a cross-sectional study of patients with AD and other eczemas. Skindex-29, Skindex-teen, and the Childhood Atopic Dermatitis Impact Scale (CADIS) were the instruments used to assess QOL in adults, teenagers, and children, respectively. The SF-12 was also used, and disease severity was evaluated using the Patient-Oriented SCORAD (PO-SCORAD) instrument. Associations with QOL were assessed based on the odds ratio (OR). $P$ values $<.05$ and $95 \%$ Cls were considered statistically significant.

Results: The study population comprised 162 participants aged $0.5-74$ years. We found that $37.3 \%$ of AD patients consider their disease disabling and that more than half of the patients feel stigmatized by society. The mean Skindex score for AD was 39.68, and the impact on QOL was severe in 44\%. "Symptoms" was the most affected category in adults. AD was moderate to severe in $87 \%$ of the sample. One of the factors that most influenced poorer QOL in $\mathrm{AD}$ was age: with increasing age, the Skindex is likely to increase $(\mathrm{OR}, 1.03 ; 95 \% \mathrm{Cl}$, 1.00-1.06). "Considering the disease a disability" was also associated (OR, 6.72; $95 \% \mathrm{Cl}, 2.56-17.63)$. QOL worsens with increasingly affected body area $(\mathrm{OR}, 1.07 ; 95 \% \mathrm{Cl}, 1.03-1.11)$ and the presence of edema $(\mathrm{OR}, 2.0 ; 95 \% \mathrm{Cl}, 1.23-3.40)$.

Conclusions: This is the first study to provide data on QOL in patients with $\mathrm{AD}$ in Portugal. Our data show an expected negative impact. More awareness-raising activities are needed to increase knowledge, decrease stigmatization, and, consequently, address the factors involved in the QOL of patients with AD.
\end{abstract}

Key words: Atopic dermatitis. Atopic eczema. Portugal. Quality of life. Skindex.

\section{Resumen}

Objetivos: Investigar la calidad de vida (QOL) y caracterizar a los pacientes con dermatitis atópica (AD) en Portugal.

Métodos: Se trata de un estudio transversal de pacientes con AD y otros eczemas. Skindex-29, Skindex-teen y Childhood Atopic Dermatitis Impact Scale (CADIS) fueron los instrumentos utilizados para evaluar la QOL en adultos, adolescentes y niños, respectivamente. También se utilizó el SF-12 y se evaluó la gravedad de la enfermedad a través del SCORAD Orientado por el paciente (PO-SCORAD). Las asociaciones con la QOL se evaluaron según la odds ratio (OR). El IC del 95\% y los valores de $p<0,05$ se consideraron estadísticamente significativos. Resultados: La población del estudio comprendió 162 participantes de entre 0,5 y 74 años. Encontramos que el 37,3\% de los pacientes con DA consideran su enfermedad como incapacitante y más de la mitad de los pacientes con DA se sienten estigmatizados por la sociedad. La puntuación media de Skindex para la AD fue de 39,68 y el impacto en la QOL fue severo en el 44\%. Síntomas"fue la categoría más afectada en los adultos. La DA fue de moderada a grave en el $87 \%$ de la muestra. Uno de los factores que más influyó en una peor calidad de vida en DA fue la edad: a medida que aumenta la edad, es probable que el Skindex aumente (OR: 1,03 [IC 95\% 1,00-1,06]). "Considerar la enfermedad como discapacidad" también se asoció, OR: 6,72 (IC 95\% 2,56-17,63). La calidad de vida también empeora con el área del cuerpo cada vez más afectada (OR: 1,07 [IC 95\% 1,03-1,11] y OR: 2.04 [IC 95\% 1,23-3,40], respectivamente). Conclusiones: Este es el primer estudio que proporciona datos sobre la calidad de vida en pacientes con DA en Portugal. Nuestros datos muestran un impacto negativo esperado. Se necesitan más actividades de sensibilización para aumentar el conocimiento, disminuir el estigma y, en consecuencia, abordar los factores involucrados en la calidad de vida de los pacientes con DA.

Palabras clave: Dermatitis atópica. Eccema atópico. Portugal. Calidad de vida. Skindex. 


\section{Introduction}

The occurrence of inflammatory chronic diseases is an increasing concern in industrialized countries. There is still no definite cure for most chronic conditions, and more attention is being paid to patient's limitations, disability, and quality of life (QOL) [1].

Assessing QOL has improved comprehension of the impact of disease among the medical community and is a good indicator in decisions regarding the most appropriate individual treatment. In addition, this assessment makes it possible to manage patients more effectively. Discussion of QOL can also be useful, as it would involve patients in choice of treatment and enable shared decision making [2].

In chronic dermatological diseases, treatments may offer temporary suppression or relief of severity and symptoms [2]. As a result, many patients must cope with the impact of their illness throughout their lifetime. Skin diseases are sometimes neglected by society and continue to receive little attention in global health discussions [3].

Atopic dermatitis (AD) is a chronic and relapsing inflammatory disease characterized by intense pruritus and very sensitive and dry skin [4]. In fact, $A D$ and other types of eczema affect patients' QOL dramatically owing to their impact on relationships and daily activities, as assessed through psychological, social, physical, and functional factors [4,5].

The paucity of data on QOL in Portuguese patients with AD highlights the importance of studying this disease. The main aims of this study were to assess patients' QOL and to determine the factors that may be associated with QOL in patients with $\mathrm{AD}$ and other eczemas. We also questioned patients about how the disease is addressed by the medical community and society and how this affects their QOL.

\section{Materials and Methods}

\section{Study Design and Population}

QUality of Life in Atopic Dermatitis and Eczema in Portugal (QUADEP) is a national, cross-sectional study that was performed in Portugal in 2018. Recruitment was based on interviews. Patients' databases were constructed beforehand with data from a previous prevalence study [6]. Of those who agreed to participate in QUADEP, 38.2\% completed the study. In order to enhance the range of patients enrolled, requests for participants were posted in clinics in Lisbon and on websites, thus making them available throughout the country. Additionally, the AD patient association Associação Dermatite Atópica Portugal (ADERMAP) assisted in the recruitment effort. Once the patient's consent was given, questionnaires were sent by post or e-mail. In addition, for those who agreed, a telephone interview was undertaken to collect additional data.

All patients provided their informed consent prior to participation, and the study was approved by the Portuguese Commission for Data Protection (CNPD) before initiation.

Only Portuguese nationals living in Portugal were included. A participant's self-reported diagnosis of AD or eczema was also a criterion for inclusion, which was assessed through the following question: "Have you ever been diagnosed with AD or eczema by a medical doctor?" Only those who answered positively were included. Patients of any age could participate. In the case of patients younger than 6 years $(n=29)$, a parent filled in the questionnaire. Other eczemas included hand eczema, contact dermatitis, and general eczema.

Sociodemographic and clinical characteristics (family history, diagnosis, concomitant allergies and treatments) were collected through a survey. Patient-reported outcomes were recorded to assess disease severity and QOL. The questions were mostly Likert scale-type, quantitative questions, yes or no lists, and multiple-choice questions.

\section{Study Outcomes}

Disease severity was assessed using the Patient OrientedSCORAD (PO-SCORAD) scale (0 [mild or no disease] to 103 [very severe disease]). A general questionnaire, the Short Form12 (SF-12), and disease-specific QOL questionnaires were also used. The disease-specific questionnaires were as follows:

- Skindex-29 for adults ( $\geq 17$ years-old)

- Skindex-teen for persons aged between 7 and 16 years and

- Childhood Atopic Dermatitis Impact Scale (CADIS) for participants aged $\leq 6$ years

The SF-12 (score 0 to 100) and the Skindex questionnaire group (score 0 to 100 ) had previously been validated in Portuguese [7]. There are no published data on the validation of Skindex-teen or CADIS.

SF-12 comprises a set of generic, coherent, and easily administered QOL measures that are evaluated through 2 dimensions: the mental component summary (MCS) scores and the physical component summary (PCS) scores. Higher values correspond to a better QOL [8].

In the questionnaires of the Skindex group, higher values indicate a worse QOL index. The Skindex cut-offs for impact on QOL were as follows: 0-30 (mild), 30-40 (moderate), and 40-100 (severe) [9-12]. In the logistic regression analysis, the impact on QOL was classified as severe versus moderate or mild according to these cut-offs.

\section{Statistical Analysis}

The analysis was made by subgroups: patients with AD and patients with other eczema.

All quantitative variables were summarized using descriptive statistics, namely, mean (SD) and median (range, ie, minimum and maximum). Qualitative variables were expressed as absolute (No.) and relative frequencies (\%). The association between 2 continuous variables was tested using the Spearman correlation; associations between categorical variables were assessed using the $\chi^{2}$ test [13].

Multiple logistic regression was used to compute adjusted odds ratios (ORs) between each simultaneous predictive factor and a binary outcome [13]. The multivariable analysis was performed with QOL as the dependent variable (severe vs nonsevere impact) controlling for age, sex, place of residence, family history of $\mathrm{AD}$, time since diagnosis, exacerbating situations, considering the disease a disability, frequent medical appointments, feeling of being supported by the medical community, talking about QOL, social stigma, PO-SCORAD dimensions, and SF-12 dimensions. 
Values of $P<.05$ were considered statistically significant, and $95 \%$ CIs were determined. All analyses were performed using IBM SPSS Statistics for Windows, Version 24.0 (IBM Corp).

Table 1. Sociodemographic and Clinical Characteristics Concerning Atopic Dermatitis and Other Eczemas

\begin{tabular}{|c|c|c|}
\hline & $\begin{array}{l}\text { Atopic Dermatitis } \\
\qquad(\mathrm{n}=134)\end{array}$ & $\begin{array}{c}\text { Other Eczemas } \\
\quad(\mathrm{n}=28)\end{array}$ \\
\hline \multicolumn{3}{|l|}{ Age, y } \\
\hline Median (min-max) & $21.50(0.5-74)$ & $43.00(9-59)$ \\
\hline $0-6$ y, No. $(\%)$ & $29(21.6)$ & $0(0.0)$ \\
\hline 7-16 y, No. (\%) & $28(20.9)$ & $3(10.7)$ \\
\hline 17-29 y, No. (\%) & $35(26.1)$ & $6(21.4)$ \\
\hline 30-39 y, No. (\%) & $14(10.4)$ & $3(10.7)$ \\
\hline 40-49 y, No. (\%) & $14(10.4)$ & $7(25.0)$ \\
\hline $50-59$ y, No. $(\%)$ & $8(6.0)$ & $9(32.1)$ \\
\hline $60-80$ y, No. (\%) & $6(4.5)$ & $0(0.0)$ \\
\hline Female, No. (\%) & $85(63.4)$ & $11(39.3)$ \\
\hline Urban residence, No. (\%) & $103(76.9)$ & $19(67.9)$ \\
\hline Family history of AD, No. (\%) & $65(48.5)$ & $9(32.1)$ \\
\hline Mother & $22(33.9)$ & $1(11.1)$ \\
\hline Father & $14(21.5)$ & $1(11.1)$ \\
\hline Grandparents and grandchildre & ren $6(9.2)$ & $2(22.2)$ \\
\hline Children & $13(20.0)$ & $2(22.2)$ \\
\hline Siblings & $14(21.5)$ & $4(44.4)$ \\
\hline $\begin{array}{l}\text { Nephews, cousins, } \\
\text { and uncle/aunts }\end{array}$ & $12(18.5)$ & $0(0.0)$ \\
\hline Other relatives & $2(3.08)$ & $1(11.1)$ \\
\hline \multicolumn{3}{|c|}{ Medical speciality that diagnosed AD, No. (\%) } \\
\hline General and family physician & $29(21.6)$ & $9(32.1)$ \\
\hline Immunoallergologist & $8(6.0)$ & $2(7.1)$ \\
\hline Dermatologist & $62(46.3)$ & $14(50)$ \\
\hline Pediatrician & $32(23.9)$ & $2(7.1)$ \\
\hline Other & $3(2.2)^{\mathrm{a}}$ & $1(3.6)^{b}$ \\
\hline \multicolumn{3}{|c|}{ Health center where the diagnosis was made, No. (\%) } \\
\hline Public hospital & $30(22.4)$ & $3(10.7)$ \\
\hline Private clinic/hospital & $73(54.5)$ & $14(50.0)$ \\
\hline Primary care & $29(21.6)$ & $10(35.7)$ \\
\hline Other & $1(0.7)^{c}$ & $0(0.0)$ \\
\hline \multicolumn{3}{|l|}{ Time since diagnosis, No. (\%) } \\
\hline Median (min-max) & $11.00(0.3-50)$ & $6.00(1-40)$ \\
\hline$<1$ y, No. $(\%)$ & $8(6.0)$ & $4(14.3)$ \\
\hline $2-5$ y, No. $(\%)$ & $32(23.9)$ & $9(32.1)$ \\
\hline $6-10$ y, No. $(\%)$ & $22(16.4)$ & $4(14.3)$ \\
\hline$>11$ y, No. $(\%)$ & $66(49.3)$ & $9(32.1)$ \\
\hline \multicolumn{3}{|l|}{ Age at diagnosis, $\mathrm{y}$} \\
\hline Mean (SD) & $8.77(12.41)$ & $27.69(15.70)$ \\
\hline Other allergic disease, No. (\%) & o) $59(44.0)$ & $1(3.6)$ \\
\hline Asthma & $9(15.3)$ & $0(0.0)$ \\
\hline Rhinitis & $22(37.3)$ & $1(100.0)$ \\
\hline Asthma and rhinitis & $4(6.8)$ & $0(0.0)$ \\
\hline Sinusitis & $3(5.1)$ & $0(0.0)$ \\
\hline Combinations & $8(13.6)$ & $0(0.0)$ \\
\hline Other & $13(22.0)$ & $0(0.0)$ \\
\hline
\end{tabular}

aPharmacist, internal medicine physician, and oncologist. bEmergency.

cPharmacy.

\section{Results}

\section{Patients}

A total of 162 participants ( 134 with AD and 28 with other eczemas) with ages ranging from 0.5 to 74 years were included in the QUADEP study.

\section{Sociodemographic and Clinical Characteristics}

Median age differed between the AD patients (21.50 years) and the eczema patients (43 years). More women with AD were interviewed (63.4\%), and most lived in an urban area $(76.9 \%)$ (Table 1). Respondents were from throughout Portugal, mainly Lisbon (25.3\%), followed by Porto (11.7\%), Setubal (11.1\%), and Santarem $(8.6 \%)$. A family history of AD was observed in $48.5 \%$ of AD patients (Table 1 ).

The initial diagnosis was mainly by a dermatologist $(46.3 \%$ for $\mathrm{AD}$ patients and $50 \%$ for eczema patients), followed by a pediatrician (23.9\% for AD patients) or a general and family physician (21.6\% for AD patients). Findings for both subgroups were also consistent in that patients preferred a private clinic for the initial diagnosis $(54.5 \%$ for AD patients and $50 \%$ for eczema patients) (Table 1 ).

Patients with AD had been diagnosed a median of 11 years previously. The average age at diagnosis was 8.77 years. Age at diagnosis was younger than 1 year in $25 \%$ and 1 year in 15\% (Table 1).

Concomitant allergic diseases were also studied; the most common were asthma and/or allergic rhinitis.

A large percentage of AD patients reported worsening of their symptoms when they sweat $(49.3 \%)$ (Table 2$)$. Stress was reported by $11.2 \%$ of $\mathrm{AD}$ and $3.6 \%$ of other eczema patients. The "other situations", as reported by $25.4 \%$ of AD patients, were contact with allergen, wind, driving (because of hand contact), ironing, sunlight, hot weather, certain chemical products, water contact (any temperature), humidity, life changes, wool, certain foods, poor sleep, make-up, tiredness, changes in the weather, proximity to trees, and physical effort.

In the case of patients with other eczemas, $34.1 \%$ reported the situations that made their conditions worse to be hand washing, contact with pollens/ground/farms, tight clothing, sports, alcoholic disinfectants and detergents, warm weather, temperature changes, and contact with savory food and plants.

\section{Characteristics of Care}

Treatment was very varied. Emollients were widely used in both subgroups $(85.5 \%$ in $\mathrm{AD}$, and $67.9 \%$ for other eczemas) (Table 2), and all patients highlighted the importance of daily application of emollient to improve their QOL. In addition to therapy, $5 \%$ of patients reported using alternative means to improve their QOL or reduce pain and discomfort, such as montelukast sodium, food supplements, folic acid, diet, homeopathy, and homeopathic creams.

Therapy was discontinued by $27.6 \%$ of AD patients. The therapies stopped included the following:

- Immunosuppressants (mainly cyclosporine and azathioprine), owing to poor effectiveness and adverse events 
- Oral corticosteroids, owing to worsening of symptoms and adverse events

- Topical corticosteroids, owing to poor effectiveness and worsening of symptoms

Table 2. Characteristics of Treatment and Care in Atopic Dermatitis and Other Eczemas

\begin{tabular}{|c|c|c|}
\hline & $\begin{array}{l}\text { topic Dermatitis } \\
\qquad(\mathrm{n}=134)\end{array}$ & $\begin{array}{l}\text { Other Eczemas } \\
\quad(\mathrm{n}=28)\end{array}$ \\
\hline \multicolumn{3}{|l|}{ Exacerbating situations, No. (\%) } \\
\hline Winter & $49(36.6)$ & $7(25.0)$ \\
\hline Spring & $55(41.0)$ & $6(21.4)$ \\
\hline Summer & $42(31.3)$ & $4(14.3)$ \\
\hline Autumn & $31(23.1)$ & $2(7.1)$ \\
\hline Animals & $31(23.1)$ & $2(7.1)$ \\
\hline Dusty areas & $42(31.3)$ & $6(21.4)$ \\
\hline At night & $26(14.4)$ & $1(3.6)$ \\
\hline Sweat & $66(49.3)$ & $3(10.7)$ \\
\hline Stressful moments & $15(11.2)$ & $1(3.6)$ \\
\hline Does not exist/Does not know & $10(7.5)$ & $5(17.9)$ \\
\hline Other & $34(25.4)$ & $9(34.1)$ \\
\hline Allergy tests, No. (\%) & $86(64.2)$ & $3(10.7)$ \\
\hline Blood tests & $59(68.6)$ & $2(66.7)$ \\
\hline Skin prick test & $65(75.6)$ & $3(100.0)$ \\
\hline Patch test & $28(32.6)$ & $0(0.0)$ \\
\hline \multicolumn{3}{|l|}{ Results, No. (\%) } \\
\hline Mites & $53(61.6)$ & $1(33.3)$ \\
\hline Pollen & $45(52.3)$ & $1(33.3)$ \\
\hline Food & $28(32.6)$ & $0(0.0)$ \\
\hline Fungi & $10(11.6)$ & $0(0.0)$ \\
\hline Animals & $32(37.2)$ & $1(33.3)$ \\
\hline Bug bite & $9(10.5)$ & $0(0.0)$ \\
\hline Drugs & $10(11.6)$ & $0(0.0)$ \\
\hline Other & $18(20.9)$ & $2(66.7)$ \\
\hline \multicolumn{3}{|l|}{ Current treatment, No. (\%) } \\
\hline Pharmacological only & $8(6.0)$ & $1(3.6)$ \\
\hline Antihistamines & $73(54.5)$ & $2(7.1)$ \\
\hline Emollients & $115(85.8)$ & $19(67.9)$ \\
\hline Immunotherapy & $11(8.2)$ & $0(0.0)$ \\
\hline $\begin{array}{l}\text { Corticosteroids (topical } \\
\text { or systemic) }\end{array}$ & $86(64.2)$ & $15(53.6)$ \\
\hline Immunosuppressants & $14(10.4)$ & $0(0.0)$ \\
\hline None & $2(1.49)$ & $3(1.85)$ \\
\hline Other & $7(5.22)$ & $0(0.0)$ \\
\hline Treatment discontinuation, No. (\%) & 6) $37(27.6)$ & $2(7.1)$ \\
\hline Clothing care, No. (\%) & $102(76.1)$ & $12(42.9)$ \\
\hline
\end{tabular}

- Oral antihistamines, owing to poor effectiveness

- Allergen immunotherapy, owing to the increase in allergy attacks

- Emollients, owing to poor effectiveness

- Antidepressants, owing to poor effectiveness

- Phototherapy, owing to poor effectiveness, worsening of symptoms, and adverse events

- Topical tacrolimus, owing to intense pruritus

- Acupuncture, owing to poor effectiveness

Apart from the treatments described above, general measures are considered important by most patients $(76.1 \%$ and $42.9 \%$ of $\mathrm{AD}$ and eczema patients, respectively). Clothing material was a concern, with $87.2 \%$ of patients preferring cotton and $35.3 \%$ avoiding wool, knitwear, synthetic and acrylic textiles, and elastic clothes. Before using something new, some patients admitted checking its material, avoiding aggressive seams, turtlenecks, and tighter clothes, as well as removing hang tags. Some patients mentioned the need to use sunglasses daily to avoid the wind or going out with light clothing in order to avoid sweating. Others stated that accessories such as belts and details in sandals can be troublesome. Regarding bedding, some patients admit to vacuum-cleaning and airing the mattress frequently, washing sheets more often and separately from the rest of the family, and using specific detergents.

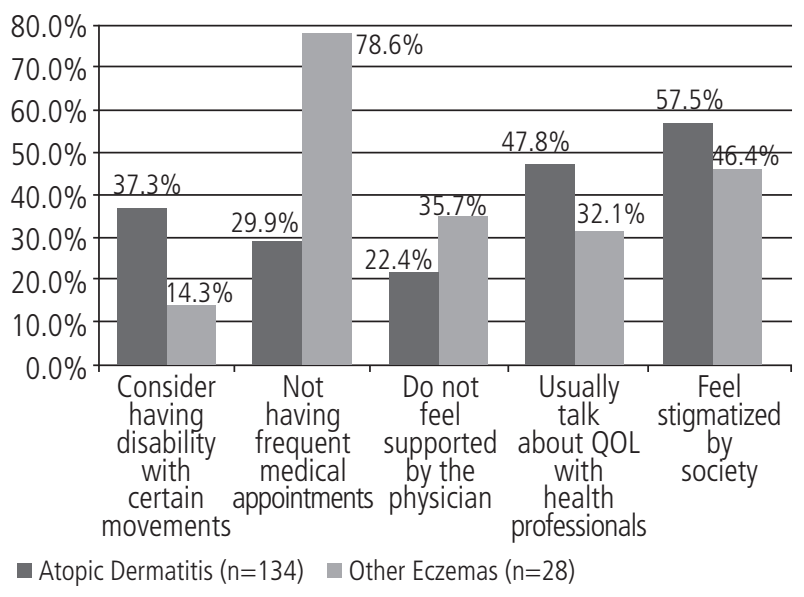

Figure. Patients' perspective regarding disability, medical support, and stigmatization according to disease subgroup.

Table 3. Skindex and PO-SCORAD Results and Respective Correlations by Disease Subgroup

\begin{tabular}{llcccc}
\hline & & \multicolumn{4}{c}{ Skindex Total Score } \\
\hline Atopic dermatitis & Disease severity & Mild $(\mathrm{n}=17)$ & Moderate $(\mathrm{n}=56)$ & Severe $(\mathrm{n}=61)$ & Overall $(\mathrm{n}=134)$ \\
& Mean (SD) & $18.52(8.81)$ & $33.09(16.68)$ & $51.57(18.95)$ & $39.68(20.66)$ \\
& Spearman coefficient & $0.661^{\mathrm{b}}$ & & & \\
\hline \multirow{2}{*}{ Other eczemas } & Disease severity & Mild $(\mathrm{n}=7)$ & Moderate $(\mathrm{n}=17)$ & Severe $(\mathrm{n}=4)$ & Overall $(\mathrm{n}=28)$ \\
& Mean (SD) & $17.03(3.87)$ & $30.35(10.15)$ & $41.81(18.68)$ & $28.66(12.87)$ \\
& Spearman coefficient & $0.672^{\mathrm{b}}$ & & &
\end{tabular}

aMeasured by PO-SCORAD score (mild, 0-25; moderate, 25-50; and severe, $\geq 50$.

${ }^{\mathrm{b}} P \leq .001$ 


\section{Quality of Life and Subjective Disease Burden}

In order to understand patients' perspectives regarding disability, medical support, and stigmatization, the assessment included subjective questions (Figure). We observed that $37.3 \%$ of $\mathrm{AD}$ patients and $14.3 \%$ of other eczema patients consider that their disease causes a certain degree of disability. A high number of patients do not attend regular medical appointments $(29.9 \%$ of $\mathrm{AD}$ patients and $78.6 \%$ of other eczema patients), and some do not feel supported by the medical community $(22.4 \%$ and $35.7 \%$, respectively). A matter of concern is how these patients feel about society's perspective. More than half of the AD patients feel stigmatized by society (Figure).

Score results are heterogeneous (Table 3). The mean QOL score for AD patients (Skindex) was 39.68, which represents a moderate impact on QOL, yet $44 \%$ of patients report a severe impact on QOL. Patients with more severe disease reported a greater impact on QOL. "Symptoms" was the most affected category in adults (Table 4).

In this sample, $87 \%$ of $\mathrm{AD}$ patients had moderate-to-severe $\mathrm{AD}$ according to PO-SCORAD $(41.8 \%$ moderate and $45.5 \%$ severe).

Table 4. Skindex-29, Skindex-teen, and CADIS Dimensions by Disease Subgroup

\begin{tabular}{|c|c|c|}
\hline & $\begin{array}{c}\text { Atopic } \\
\text { Dermatitis } \\
(\mathrm{n}=134)\end{array}$ & $\begin{array}{c}\text { Other } \\
\text { eczemas } \\
(n=28)\end{array}$ \\
\hline $\begin{array}{l}\text { Skindex-29, Functioning dimension score } \\
\text { Mean (SD) }\end{array}$ & $\begin{array}{c}n=77 \\
35.10 \\
(24.00)\end{array}$ & $\begin{array}{c}n=25 \\
16.58 \\
(14.54)\end{array}$ \\
\hline $\begin{array}{l}\text { Skindex-29, Emotions dimension score } \\
\text { Mean (SD) }\end{array}$ & $\begin{array}{c}n=77 \\
46.74 \\
(22.18)\end{array}$ & $\begin{array}{c}n=25 \\
33.72 \\
(16.04)\end{array}$ \\
\hline $\begin{array}{l}\text { Skindex-29, Symptoms dimension score } \\
\text { Mean (SD) }\end{array}$ & $\begin{array}{c}n=77 \\
62.78 \\
(15.99)\end{array}$ & $\begin{array}{c}n=25 \\
47.29 \\
(14.18)\end{array}$ \\
\hline $\begin{array}{l}\text { Skindex-teen, PS dimension score } \\
\text { Mean (SD) }\end{array}$ & $\begin{array}{c}n=28 \\
53.75 \\
(16.59)\end{array}$ & $\begin{array}{c}n=3 \\
35.0 \\
(10.0)\end{array}$ \\
\hline $\begin{array}{l}\text { Skindex-teen, PF dimension score } \\
\text { Mean (SD) }\end{array}$ & $\begin{array}{c}n=28 \\
31.34 \\
(22.49)\end{array}$ & $\begin{array}{c}\mathrm{n}=3 \\
47.29 \\
(14.18)\end{array}$ \\
\hline $\begin{array}{l}\text { CADIS, Family dimension score } \\
\text { Mean (SD) }\end{array}$ & $\begin{array}{c}\mathrm{n}=29 \\
15.8(20.41)\end{array}$ & - \\
\hline $\begin{array}{l}\text { CADIS, Emotions dimension score } \\
\text { Mean (SD) }\end{array}$ & $\begin{array}{c}n=29 \\
27.99(18.40)\end{array}$ & - \\
\hline $\begin{array}{l}\text { CADIS, Sleep dimension score } \\
\text { Mean (SD) }\end{array}$ & $\begin{array}{c}\mathrm{n}=29 \\
17.82(21.48)\end{array}$ & - \\
\hline $\begin{array}{l}\text { CADIS, Symptoms dimension score } \\
\text { Mean (SD) }\end{array}$ & $\begin{array}{c}n=29 \\
42.86(26.11)\end{array}$ & - \\
\hline $\begin{array}{l}\text { CADIS, Activities dimension score } \\
\text { Mean (SD) }\end{array}$ & $\begin{array}{c}\mathrm{n}=29 \\
22.74(17.98)\end{array}$ & - \\
\hline
\end{tabular}

Abbreviations: CADIS, Childhood Atopic Dermatitis Impact Scale; NA, not applicable; PF, psychosocial functioning; PS, physical symptoms.
Table 5. Correlations Between Skindex or PO-SCORAD and SF-12, by Disease Subgroup (Spearman Coefficient)

\begin{tabular}{llcc}
\hline & & MCS & PCS \\
\hline \multirow{2}{*}{ Atopic dermatitis } & PO-SCORAD & $-0.265^{\mathrm{a}}$ & $-0.453^{\mathrm{b}}$ \\
& Skindex & $-0.451^{\mathrm{b}}$ & $-0.337^{\mathrm{b}}$ \\
Other eczemas & PO-SCORAD & -0.369 & $-0.377^{\mathrm{a}}$ \\
& Skindex & -0.349 & $-0.385^{\mathrm{a}}$
\end{tabular}

Abbreviations: MCS, mental component summary; PCS, physical component summary; SF-12, Short Form-12 questionnaire. a $P \leq .05$

${ }^{\mathrm{b}} P \leq .001$

The MCS and PCS results complemented the study of QOL, with high values that match those from Skindex (Table 5).

\section{Factors That Can Affect QOL}

Regarding the factors that most negatively influence QOL, we found that "time since diagnosis" was statistically significantly related to the total Skindex score $(\mathrm{r}=0.404$; $P<.001)$ and to clinical severity $(\mathrm{r}=0.324 ; P<.001)$. This implies that QOL worsens over the years and that persistent $\mathrm{AD}$ is clinically more severe.

Age was statistically significantly related to severity $(\mathrm{r}=0.305 ; \mathrm{P}<.001)$ and with the Skindex score $(\mathrm{r}=0.392$; $P<.001)$. With increasing age, the Skindex score is likely to increase (OR, $1.028 ; 95 \% \mathrm{CI}, 1.008-1.049 ; P=.007)$, ie, worse QOL.

Among the situations that can exacerbate the disease, "dusty areas" and "at night" were the ones most associated with the Skindex score (OR, 2.451 [95\%CI, 1.118-5.373; $P=.025]$ and OR, 3.940 [95\%CI, $1.490-10.417 ; P=.006]$, respectively).

"Considering the disease a disability" and "feeling stigmatized by society" were also associated with the Skindex score (OR, 9.349 [95\%CI, 4.134-21.146; $P<.001]$ and OR,14.857 [95\%CI, 5.899-37.417; $P<.001]$, respectively).

We also performed a multivariable analysis to investigate the associations between worse QOL score and several variables (Table 6).

\section{Discussion}

This is the first study to provide a comprehensive overview of the QOL of AD patients in Portugal. Since there is no Portuguese registry for $\mathrm{AD}$, we chose to send the survey by post or e-mail, an approach that has been increasingly used in recent years [14-16]. We enrolled 162 patients of varying ages. However, our pediatric sample was very small, and most cases were mild or moderate. The 3 instruments used (Skindex, PO-SCORAD, and SF-12) were highly correlated.

The overall mean Skindex score for AD was 39.68 on a scale of 0 to 100 , representing a moderate impact on QOL. Since we had a heterogeneous sample comprising patients with mild, moderate, and severe $\mathrm{AD}$, the mean Skindex score for each grade of severity was $18.52,33.09$, and 51.57 , respectively. For adults, "Symptoms" was the dimension with the highest score for all subgroups. Similarly, among teenagers 
Table 6. Multivariable Logistic Regression for Atopic Dermatitis

\begin{tabular}{|c|c|c|c|c|c|c|c|}
\hline Predictor Variable & Skindex ${ }^{a}$ & $\begin{array}{l}\text { Predictor } \\
\text { Variable }\end{array}$ & Disability $^{\mathrm{b}}$ & $\begin{array}{l}\text { Predictor } \\
\text { Variable }\end{array}$ & $\begin{array}{l}\text { Having Medical } \\
\text { Appointments }^{c}\end{array}$ & $\begin{array}{l}\text { Predictor } \\
\text { Variable }\end{array}$ & $\begin{array}{c}\text { Feeling } \\
\text { Supported }^{\mathrm{d}}\end{array}$ \\
\hline & $\begin{array}{c}\text { Atopic } \\
\text { Dermatitis }\end{array}$ & & $\begin{array}{c}\text { Atopic } \\
\text { Dermatitis }\end{array}$ & & $\begin{array}{c}\text { Atopic } \\
\text { Dermatitis }\end{array}$ & & $\begin{array}{c}\text { Atopic } \\
\text { Dermatitis }\end{array}$ \\
\hline Age $(95 \% \mathrm{CI})$ & $\begin{array}{c}\text { OR, 1.03* } \\
(1.00-1.06)\end{array}$ & $\begin{array}{c}\text { Disease worsens } \\
\text { when sweating } \\
(95 \% \mathrm{CI})\end{array}$ & $\begin{array}{c}\text { OR, } 3.50 * \\
(1.22-10.07)\end{array}$ & $\begin{array}{c}\text { Disease } \\
\text { worsens when } \\
\text { sweating } \\
(95 \% \mathrm{CI})\end{array}$ & $\begin{array}{l}\text { OR, 3.51* } \\
(1.36-9.03)\end{array}$ & $\begin{array}{l}\text { Considering } \\
\text { the disease } \\
\text { a disability } \\
(95 \% \mathrm{CI})\end{array}$ & $\begin{array}{c}\text { OR, 10.73* } \\
(2.07-55.62)\end{array}$ \\
\hline $\begin{array}{l}\text { Considering } \\
\text { the disease } \\
\text { a disability } \\
(95 \% \mathrm{CI})\end{array}$ & $\begin{array}{c}\text { OR, 6.72** } \\
(2.56-17.63)\end{array}$ & $\begin{array}{l}\text { Skindex } \\
\text { Total score } \\
(95 \% \mathrm{CI})\end{array}$ & $\begin{array}{l}\text { OR, } 1.07 * * \\
(1.03-1.10)\end{array}$ & $\begin{array}{l}\text { Feeling } \\
\text { supported by } \\
\text { medical } \\
\text { community } \\
(95 \% \mathrm{CI})\end{array}$ & $\begin{array}{l}\text { OR, } 21.55^{* *} \\
(6.38-72.81)\end{array}$ & $\begin{array}{c}\text { Having } \\
\text { medical } \\
\text { appointments } \\
(95 \% \mathrm{CI})\end{array}$ & $\begin{array}{l}\text { OR, 48.09** } \\
(8.10-257.05)\end{array}$ \\
\hline $\begin{array}{l}\text { Affected area } \\
(95 \% \mathrm{CI})\end{array}$ & $\begin{array}{l}\text { OR, } 1.07 * * \\
(1.03-1.11)\end{array}$ & $\begin{array}{c}\text { PCS } \\
(95 \% \mathrm{CI})\end{array}$ & $\begin{array}{l}\text { OR, } 0.91 * \\
(0.85-0.97)\end{array}$ & $\begin{array}{c}\text { Final } \\
\text { PO-SCORAD } \\
\text { score } \\
(95 \% \mathrm{CI})\end{array}$ & $\begin{array}{l}\text { OR, } 1.05 * * \\
(1.02-1.09)\end{array}$ & $\begin{array}{c}\text { Feeling } \\
\text { stigmatized } \\
\text { by society } \\
(95 \% \mathrm{CI})\end{array}$ & $\begin{array}{l}\text { OR, } 0.147^{*} \\
(0.03-0.76)\end{array}$ \\
\hline \multirow[t]{5}{*}{$\begin{array}{l}\text { Edema } \\
(95 \% \mathrm{CI})\end{array}$} & $\begin{array}{l}\text { OR, 2.04* } \\
(1.23-3.40)\end{array}$ & & & & & $\begin{array}{c}\text { Final } \\
\text { PO-SCORAD } \\
\text { score } \\
(95 \% \mathrm{CI})\end{array}$ & $\begin{array}{l}\text { OR, } 0.89 * * \\
(0.83-0.94)\end{array}$ \\
\hline & & & & & & $\begin{array}{c}\text { Sex } \\
(95 \% \mathrm{CI})\end{array}$ & $\begin{array}{c}\text { OR, } 0.21^{*} \\
(0.05-0.85)\end{array}$ \\
\hline & & & & & & $\begin{array}{l}\text { Disease worsens } \\
\text { in winter } \\
(95 \% \mathrm{CI})\end{array}$ & $\begin{array}{c}\text { OR, } 0.13 * \\
(0.03-0.53)\end{array}$ \\
\hline & & & & & & $\begin{array}{l}\text { Disease worsens } \\
\text { in autumn } \\
(95 \% \mathrm{CI})\end{array}$ & $\begin{array}{c}\text { OR, 5.03* } \\
(1.01-25.09)\end{array}$ \\
\hline & & & & & & $\begin{array}{l}\text { Disease worsens } \\
\text { when sweating } \\
(95 \% \mathrm{CI})\end{array}$ & $\begin{array}{c}\mathrm{OR}, 0.25^{*} \\
(0.07-0.91)\end{array}$ \\
\hline $\begin{array}{l}\text { ROC curve } \\
(95 \% \mathrm{CI})\end{array}$ & $\begin{array}{r}\text { Area, } 0.867 * * \\
(0.801-0.934)\end{array}$ & & $\begin{array}{c}\text { Area, } 0.865^{* *} \\
(0.789-0.941)\end{array}$ & & $\begin{array}{l}\text { Area, } 0.818^{* *} \\
(0.741-0.895)\end{array}$ & & $\begin{array}{c}\text { Area, } 0.924 * * \\
(0.875-0.972)\end{array}$ \\
\hline
\end{tabular}

aDependent variable is Skindex score ( $1=$ severe score, $0=$ little, mild and moderate score)

bependent variable is disability $(1=$ Yes, $0=$ No)

'Dependent variable is having regular medical appointments $(1=\mathrm{Yes}, 0=\mathrm{No})$

dDependent variable is feeling supported by medical community ( $1=$ Yes, $0=$ No)

${ }^{*} P \leq .05$

** $P \leq .001$

The independent variables were age, affected area, edema, oozing/crusts, Skindex Total Score, PO-SCORAD score, PCS and MCS as continuous variables; and disability, exacerbating situations, feeling supported, having medical support and feeling stigmatized by society (reference, no); independent variable sex (reference, male).

Abbreviations: MCS, mental component summary; PCS, physical component summary; ROC, receiver operating characteristic.

and children with $\mathrm{AD}$, the "Psychosocial functioning" and "Symptoms" dimensions, respectively, yielded the highest scores. Two previous studies in the Netherlands and Australia with patients aged $>2$ years reported a mean Skindex-29 score of 39.7 and $58.6[17,18]$. Other previous studies in AD adults revealed a mean Skindex score of 20-30; "Symptoms" was also the dimension with the highest values $[19,20]$. Japanese adults reported a mean (SD) Skindex-16 score of 50 (23) (66 [17] in those with severe disease), although the dimension with the highest score was "Emotions", with a mean score of
64 (40) [21]. The dimension "Physical symptoms" has also been reported to have the highest values [22].

Other widely used instruments include the Dermatology Life Quality Index (DLQI), although the conclusion follows the same path: $\mathrm{AD}$ has a strong negative impact on QOL, and "Symptoms" is the dimension with the strongest impact, both in adults and in children [23-27].

Female sex and increasing age are risk factors for eczema and AD [15,16,28], as are environmental factors [29,30]. Our sample was a convenience sample. In a representative sample, 
we could hypothesize that these factors would influence QOL in the same way. Nonetheless, we found that with increasing age, both severity $(\mathrm{r}=0.305 ; P<.001)$ and QOL scores become worse in AD patients $(\mathrm{r}=0.392 ; P<.001)$.

As for environment, we found no differences between patients living in rural and urban areas, perhaps because our sample was predominantly urban. However, AD patients who report feeling worse when in dusty areas have a $2.451(95 \% \mathrm{CI}$, $1.118-5.373 ; P=.025)$ times greater chance of a negative impact on QOL. In addition, AD patients whose condition worsens at night were 3.940 times more likely to have a negative impact on QOL.

As genetics is also important with respect to onset of disease, family history is often associated with AD or eczema [16,31], which is inherited mainly from the mother [32]. Our sample corroborates this finding, with $48.5 \%$ of $\mathrm{AD}$ patients and $32.1 \%$ of other eczema patients having a positive family history, especially with the mother $(33.9 \%$ of AD patients).

When they first experienced symptoms, patients mostly consulted a dermatologist, a general and family physician, or a pediatrician. Patients with $\mathrm{AD}$ and other eczemas preferred a clinic or private hospital to a public center for the initial diagnosis.

This disease can worsen during childhood or adulthood, and, as a result, time since diagnosis and age at diagnosis can vary. In our subgroups, intervals were observed between 0.3 and 50 years after diagnosis. Most AD patients were diagnosed when 0-1 years old and still have the disease in adulthood.

Treatment is increasingly targeted at reducing disease severity or at increasing patients' QOL [33]. The usual treatments include antihistamines, topical and oral corticosteroids, and immunosuppressants. Continuous application of emollients is an important treatment $[28,34]$, with $85.8 \%$ of $\mathrm{AD}$ patients reporting their use, as well as $67.9 \%$ of other eczema patients. Some of these patients reported daily use of emollients, shower gel, and shampoo and that without the emollients their pain is unbearable, sometimes preventing them from moving. A German study also reported emollients to be the most frequently used treatment (by $90.4 \%$ of all patients) [24]. Additionally, we found that $5 \%$ of patients reported changes to diet and alternative treatment options, because they saw differences in their disease following the changes.

"Pharmacological only" was thought to be marked by patients who only take medication, and not emollients, vaccines, or any other "self-administered technique", as reported by many other patients. Nevertheless, this topic was not well understood, and some patients simultaneously reported "pharmacologic only" and emollients or others.

Responses about treatment, treatment discontinuation, and clothing care clearly indicated the degree of patients' perseverance. Apart from the conventional treatments or advice about emollients or clothing, patients improve their QOL by experimenting with what is better or worse for their skin. In the present study, patients reported spending around $€ 200$ per month on emollients (moisturizing creams, shampoo, or shower gel). A German study on willingness to pay affirmed that patients with $A D$ would pay $€ 1000$ per month for sustainable healing [35].
Society tends to underestimate skin diseases [36]. Around $58 \%$ and $46 \%$ of patients with $\mathrm{AD}$ and eczema, respectively, declared feeling that their disease is unappreciated by society, and some teenagers complained of bullying at school, as reported elsewhere $[5,37,38]$. In addition, more than half of patients generally do not talk to a health professional about their QOL. More data on this topic in Portugal are needed. In fact, we observed that $22.4 \%$ of $\mathrm{AD}$ patients and $35.7 \%$ of other eczema patients do not feel supported by physicians, thus possibly explaining why some do not have regular appointments. A previous study on this issue reported that QOL was not addressed in $40 \%$ of consultations with a specialist. In appointments where QOL was discussed, this was more likely to be with specialist nurses than with clinicians [39].

Similar findings have been reported elsewhere. In Japan, AD patients do not usually visit a physician [40]. Assessment of patients' satisfaction with the physician's care using a VAS yielded a score of 59.6, and patients with severe disease were satisfied significantly less often [26]. Most of the patients, even those who did not feel social stigma, explained that knowledge is lacking and that questions from or situations with other people make them feel uncomfortable. Such situations have been reported in other studies, thus confirming the existence of social stigma $[27,38]$.

Patients also described situations that were not questioned, for instance, when the skin hurts and bleeds, they cannot go to the toilet or take a shower alone. They also find that their skin is so "rough" that it is awkward to touch/see and that by being prohibited from taking part in enjoyable activities, they are made to feel that they are the ones making things worse.

In summary, we found that the QOL of patients with $\mathrm{AD}$ is negatively affected by age and other exacerbating situations, as explained above. In addition, patients with worse QOL indexes consider that the disease causes disability and feel stigmatized.

The multivariable regression models revealed that "considering the disease a disability", with the increasing age, greater area affected, and more marked edema all increase the impact on QOL. Affected body surface area was also found to be a predictor factor of worse QOL [35].

"Considering the disease a disability" is influenced by patients whose disease worsens when sweating. Patients with high Skindex scores and patients with a low physical component score (SF-12), ie, negative impact on QOL, consider that the disease causes disability.

Patients whose disease worsens when sweating and those who feel supported by the medical community often have more regular medical appointments, as do those with more severe disease (high PO-SCORAD score).

Lastly, "considering the disease a disability" and having regular medical appointments increase the feeling of support. Nonetheless, in our study, patients who did not feel stigmatized and had less severe disease felt more supported by the medical community. Being female is a predictor factor of worse QOL for patients who do not feel supported by the medical community.

Our study is limited by the fact that the sample was not representative. In addition, the patients self-reported their diagnosis of $\mathrm{AD}$, although all patients confirmed that the diagnosis had been made by a physician. 
While our study focused on the patient's perspective, there is evidence that the correlations between the patient's and the physician's perspective differ little [23]. Since this is the first study to address QOL in patients with AD in Portugal, we decided to listen to the patients first. However, much remains to be done regarding future studies and actions in Portugal. As noted above, it is important to assess the patientphysician relationship in order to involve the patient more in decisions regarding treatment and lifestyle. Patients with AD have enormous perseverance. There is wide heterogeneity in severity, areas affected, and conditions that worsen the disease. These diseases vary daily, and it is important to listen more to patients, who best know how the disease behaves. To improve QOL, the focus should be not only on the treatment, but also on the "techniques" patients already know and apply, such as choices about clothing, cleaning, emollients, and showering. In addition, it is important to implement more awareness-raising activities in order to educate society, decrease social stigma, and thus resolve some of the factors affecting the psychological well-being of patients with AD and eczema.

\section{Acknowledgments}

The authors would like to thank Mariana Nunes for her support during data collection. We are also grateful to John Stewart Huffstot for reviewing language and style.

\section{Funding}

This study was funded by LEOPharma.

\section{Conflicts of Interest}

P. Mendes-Bastos has worked as a consultant/speaker for AbbVie, Pfizer, Janssen-Cilag, LEOPharma, Novartis, Sanofi, Teva, Bayer, and L'Oreal and has participated as a researcher in clinical trials sponsored by Novartis and AbbVie.

The other authors declare that they have no conflicts of interest.

\section{References}

1. Bonita R, Beaglehole R, Kjellstrom T. Basic epidemiology. 2nd edition. Geneva: World Health Organization. 2006.

2. van Cranenburgh OD, Prinsen CAC, Sprangers MAG, Spuls $\mathrm{PI}$, de Korte J. Health-related quality-of-life assessment in dermatologic practice: relevance and application. Dermatol Clin. 2012;30:323-32.

3. Hay RJ, Johns NE, Williams HC, Bolliger IW, Dellavalle RP, Margolis DJ, et al. The global burden of skin disease in 2010: an analysis of the prevalence and impact of skin conditions. J Invest Dermatol. 2013;134:1527-34.

4. Coutanceau C, Stalder J. Analysis of correlations between patient-oriented SCORAD (PO-SCORAD) and other assessment scores of atopic dermatitis severity and quality of life. Dermatology. 2014;229:248-55.

5. Rehal B, Armstrong AW. Health outcomes in atopic dermatitis. Dermatol Clin. 2012;30:73-86.
6. Carvalho D, Aguiar P, Ferrinho P, Mendes-Bastos P, PalmaCarlos A. Eczema and urticaria in the adult population in Portugal: a prevalence study. Actas Dermosifiliograf. 2019;110(9):744-51.

7. Carvalho D, Aguiar P, Palma-Carlos A. Validation of the skindex-29 questionnaire: Portuguese version (Portugal). Acta Med Port. 2018;31:463-9.

8. SF-12v2 Health Survey. (https://www.optum.com/solutions/ life-sciences/answer-research/patient-insights/sf-healthsurveys/sf-12v2-health-survey.html). Accessed 28 January 2019.

9. Prinsen CAC. Interpretation of Skindex-29 scores: cutoffs for mild, moderate, and severe impairment of health-related quality of life. J Invest Dermatol. 2011;131:1945-7.

10. Prinsen $C A C$, Lindeboom $R$, Sprangers $M A G$, Legierse $C M$. Health-related quality of life assessment in dermatology: interpretation of Skindex-29 scores using patient-based anchors. J Invest Dermatol. 2010;130:1318-23.

11. Nijsten T, Sampogna F, Abeni D. Categorization of Skindex-29 scores using mixture analysis. Dermatology. 2009;218:151-4.

12. Sampogna F, Abeni D. Interpretation of Skindex-29 scores. J Invest Dermatol. 2011;131:1790-3.

13. Aguiar P. Estatística em investigação epidemiológica: SPSS guia prático de medicina. Lisboa: Climepsi Editore. 2007.

14. de Marco R, Pesce G, Marcon A, Accordini S, Antonicelli $L$, Bugiani $M$, et al. The coexistence of asthma and chronic obstructive pulmonary disease (COPD): prevalence and risk factors in young, middle-aged and elderly people from the general population. PLoS One. 2013;8:e62985.

15. Pesce G, Marcon A, Carosso A, Antinicelli L, Cazzoletti L, Ferrari $M$, et al. Adult eczema in Italy: prevalence and associations with environmental factors. J Eur Acad Dermatology Venereol. 2015;29:1180-7.

16. Rönmark EP, Ekerljung L, Lötvall J, Wennergren $G$, Rönmark $E$, Torén $\mathrm{K}$, et al. Eczema among adults: prevalence, risk factors and relation to airway diseases. results from a large-scale population survey in Sweden. Br J Dermatol. 2012;166:13018.

17. Brenninkmeijer $E$, Spuls PI, Legierse CM, Lindeboom R, Smitt $H$, Bos JD. Clinical differences between atopic and atopiform dermatitis. J Am Acad Dermatol. 2008;58:407-14.

18. Zhao C, Tran A, Lazo-Dizon J, Kim J, Daniel B, Venugopal S, et al. A pilot comparison study of four clinician-rated atopic dermatitis severity scales. Br J Dermatol. 2015;173:488-97.

19. Sanclemente G, Burgos C, Nova J, Hernández F, González C, Reyes $M$, et al. The impact of skin diseases on quality of life: a multicenter study. Actas Dermosifiliogr. 2017; 108:244-52.

20. Vinding G, Knudsen K, Ellervik C, Olesen A, Jemec G. Selfreported skin morbidities and health-related. Dermatology. 2014;228:261-8.

21. Higaki Y, Kawamoto K, Kamo T, Ueda S, Arikawa J, Kawashima M. Measurement of the impact of atopic dermatitis on patients' quality of life: a cross-sectional and longitudinal questionnaire study using the Japanese version of skindex-16. J Dermatol. 2004;31:977-82.

22. Smidt AC, Lai J-S, Cella D, Patel S, Mancini AJ, Chamlin SL. Development and validation of skindex-teen, a quality-of-life instrument for adolescents with skin disease. Arch Dermatol. 2010;146:865-9. 
23. Holm EA, Wulf $H C$, Stegmann $H$, Jemec GBE. Life quality assessment among patients with atopic eczema. Br J Dermatol. 2006;154:719-25.

24. Langenbruch A, Radtke M, Franzke N, Ring J, Foelster-Holst R, Augustin M. Quality of health care of atopic eczema in Germany: results of the national health care study AtopicHealth. J Eur Acad Dermatology Venereol. 2014;28:719-26.

25. Misery L, Seneschal J, Reguiai Z, Merhand S, Héas S, Huet F, et al. Patient burden is associated with alterations in quality of life in adult patients with atopic dermatitis: results from the ECLA Study. Acta Derm Venereol. 2018;98:713-4.

26. Schmitt J, Csötönyi F, Bauer A, Meurer M. Determinants of treatment goals and satisfaction of patients with atopic eczema. J Dtsch Dermatol Ges. 2008;6:458-66.

27. Wittkowski A, Richards HL, Griffiths C, Main C. The impact of psychological and clinical factors on quality of life in individuals with atopic dermatitis. J Psychosom Res. 2004;57:195-200.

28. Barata LT, Santos AS, Fonseca AM, Todo-Bom A, Lopes A, Moreira $A$, et al. Fundamentos de imunoalergologia: da epidemiologia ao tratamento. 1a. Lisboa: Lidel. 2011.

29. World Allergy Organization. WAO: white book on allergy. 1st edition. Wisconsin: World Allergy Organization. 2013.

30. Schram ME, Tedja AM, Spijker R, Bos JD, Williams HC, Spuls PI. Is there a rural/urban gradient in the prevalence of eczema? A systematic review. Br J Dermatol. 2010;162:964-73.

31. Montnemery P, Nihlén U, Göran Löfdahl C, Nyberg P, Svensson A. Prevalence of self-reported eczema in relation to living environment, socio-economic status and respiratory symptoms assessed in a questionnaire study. BMC Dermatol. 2003;3:6.

32. Harrop J, Chinn S, Verlato G, Olivieri M, Norbäck D, Wjst $\mathrm{M}$, et al. Eczema, atopy and allergen exposure in adults: a population-based study. Clin Exp Allergy. 2007;37:526-35.

33. Prinsen CAC, de Korte J, Augustin M, Sampogna F, Salek SS, Basra MKA, et al. Measurement of health-related quality of life in dermatological research and practice: outcome of the EADV taskforce on quality of life. J Eur Acad Dermatology Venereol. 2013;27:1195-203.
34. Furue $M$, Chiba $T$, Tsuju G, Ulzii D, Kido-Nakahara $M$ Nakahara T, et al. Atopic dermatitis: immune deviation, barrier dysfunction, IgE autoreactivity and new therapies. Allergol Int. 2017;66:398-403

35. Beikert FC, Langenbruch A, Radtke MA, Kornek T, Purwins S, Augustin M. Willingness to pay and quality of life in patients with atopic dermatitis. Arch Dermatol Res. 2014;306:279-86.

36. Bingefors K, Svensson $\AA$, Isacson D, Lindberg M. Self-reported lifetime prevalence of atopic dermatitis and comorbidity with asthma and eczema in adulthood: a populationbased crosssectional survey. Acta Derm Venereol. 2013;93:438-41.

37. Halvorsen JA, Lien L, Dalgard F, Bjertness E, Stern RS. Suicidal ideation, mental health problems, and social function in adolescents with eczema: a population-based study. J Invest Dermatol. 2014;134:1847-54.

38. Roosta N, Black D, Peng D, Riley L. Skin disease and stigma in emerging adulthood: impact on healthy development. J Cutan Med Surg. 2010;14:285-90.

39. David S, Ahmed Z, Salek M, Finlay A. Does enough quality of life related discussion occur during dermatology outpatient consultations? Br J Dermatol. 2005:153:997-1000.

40. Arima K, Gupta S, Gadkari A, Hiragun T, Kono T, Katayama I, et al. Burden of atopic dermatitis in Japanese adults: analysis of data from the 2013 National Health and Wellness Survey. J Dermatol. 2018;45:390-6.

- Manuscript received May 11, 2019; accepted for publication August 19, 2019.

\section{Daniela Carvalho}

Avenida Padre Cruz, 1600-560, Lisboa, Portugal

E-mail: df.carvalho@ensp.unl.pt 